\title{
Carcinoma of the Conjunctiva Pathologic Distant Metastasis TNM Finding v7
}

National Cancer Institute

\section{Source}

National Cancer Institute. Carcinoma of the Conjunctiva Pathologic Distant Metastasis

TNM Finding v7. NCI Thesaurus. Code C88606.

A pathologic finding about one or more characteristics of carcinoma of the conjunctiva, following the rules of the TNM AJCC V7 classification system as they pertain to distant metastases. There is no pathologic MO for carcinoma of the conjunctiva. (from AJCC 7th Ed.) 